NASA/TM-2004-213182

ARL-TR-3158
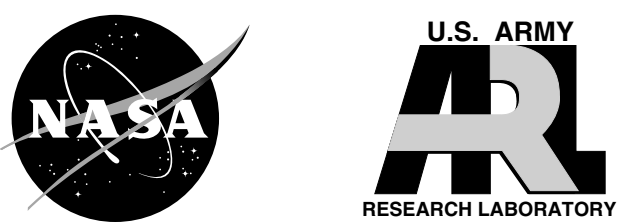

Experimental Investigation of Diffuser Hub Injection to Improve Centrifugal Compressor Stability

Gary J. Skoch

U.S. Army Research Laboratory, Glenn Research Center, Cleveland, Ohio 
Since its founding, NASA has been dedicated to the advancement of aeronautics and space science. The NASA Scientific and Technical Information (STI) Program Office plays a key part in helping NASA maintain this important role.

The NASA STI Program Office is operated by Langley Research Center, the Lead Center for NASA's scientific and technical information. The NASA STI Program Office provides access to the NASA STI Database, the largest collection of aeronautical and space science STI in the world. The Program Office is also NASA's institutional mechanism for disseminating the results of its research and development activities. These results are published by NASA in the NASA STI Report Series, which includes the following report types:

- TECHNICAL PUBLICATION. Reports of completed research or a major significant phase of research that present the results of NASA programs and include extensive data or theoretical analysis. Includes compilations of significant scientific and technical data and information deemed to be of continuing reference value. NASA's counterpart of peerreviewed formal professional papers but has less stringent limitations on manuscript length and extent of graphic presentations.

- TECHNICAL MEMORANDUM. Scientific and technical findings that are preliminary or of specialized interest, e.g., quick release reports, working papers, and bibliographies that contain minimal annotation. Does not contain extensive analysis.

- CONTRACTOR REPORT. Scientific and technical findings by NASA-sponsored contractors and grantees.
- CONFERENCE PUBLICATION. Collected papers from scientific and technical conferences, symposia, seminars, or other meetings sponsored or cosponsored by NASA.

- SPECIAL PUBLICATION. Scientific, technical, or historical information from NASA programs, projects, and missions, often concerned with subjects having substantial public interest.

- TECHNICAL TRANSLATION. Englishlanguage translations of foreign scientific and technical material pertinent to NASA's mission.

Specialized services that complement the STI Program Office's diverse offerings include creating custom thesauri, building customized databases, organizing and publishing research results ... even providing videos.

For more information about the NASA STI Program Office, see the following:

- Access the NASA STI Program Home Page at http://www.sti.nasa.gov

- E-mail your question via the Internet to help@sti.nasa.gov

- Fax your question to the NASA Access Help Desk at 301-621-0134

- Telephone the NASA Access Help Desk at 301-621-0390

- Write to:

NASA Access Help Desk

NASA Center for AeroSpace Information 7121 Standard Drive

Hanover, MD 21076 
NASA/TM-2004-213182

ARL-TR-3158
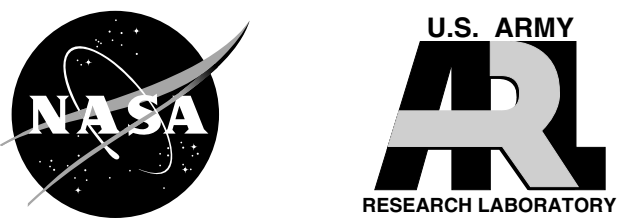

\section{Experimental Investigation of Diffuser Hub Injection to Improve Centrifugal Compressor Stability}

Gary J. Skoch

U.S. Army Research Laboratory, Glenn Research Center, Cleveland, Ohio

National Aeronautics and

Space Administration

Glenn Research Center 


\section{Acknowledgments}

The author would like to thank Thomas Jett, Winston Johnson, and Antonio Zaldana for test cell operation; Scott Panko, Edith Parrott, and Harry Fuller for electronics support; and Mark Stevens for hardware design. Special thanks also go to Dr. Anthony Strazisar for both programmatic and technical support of the project.

This work was sponsored by the Low Emissions Alternative

Power Project of the Vehicle Systems Program at the NASA Glenn Research Center.

Available from

NASA Center for Aerospace Information 7121 Standard Drive

Hanover, MD 21076
National Technical Information Service 5285 Port Royal Road Springfield, VA 22100 


\title{
Experimental Investigation of Diffuser Hub Injection to Improve Centrifugal Compressor Stability
}

\author{
Gary J. Skoch \\ U.S. Army Research Laboratory \\ Glenn Research Center \\ Cleveland, Ohio 44135
}

\begin{abstract}
Results from a series of experiments to investigate whether centrifugal compressor stability could be improved by injecting air through the diffuser hub surface are reported. The research was conducted in a 4:1 pressure ratio centrifugal compressor configured with a vane-island diffuser.

Injector nozzles were located just upstream of the leading edge of the diffuser vanes. Nozzle orientations were set to produce injected streams angled at $-8,0$ and +8 degrees relative to the vane mean camber line. Several injection flow rates were tested using both an external air supply and recirculation from the diffuser exit. Compressor flow range did not improve at any injection flow rate that was tested and generally diminished as injection rate increased.

Compressor flow range did improve slightly at zero injection due to the flow resistance created by injector openings on the hub surface. Resistance and flow range both increased as the injector orientation was turned toward radial. Leading edge loading and semi-vaneless space diffusion show trends that are similar to those reported earlier from shroud surface experiments that did improve compressor range. Opposite trends are seen for hub injection cases where compressor flow range decreased.

The hub injection data further explain the range improvement provided by shroud-side injection and suggest that stability factors cited in the discussion of shroud surface techniques are valid. The results also suggest that a different application of hub-side techniques may produce a range improvement in centrifugal compressors.
\end{abstract}

\section{Introduction}

Experiments to determine the causes, precursors and control mechanisms for stall and surge in a centrifugal compressor were conducted at the NASA Glenn Research Center over the past several years. The experimental work included an evaluation of the benefits of air injection into the centrifugal compressor diffuser using nozzles employed on both the hub and shroud surfaces. The effects of bleed tubes inserted into the vaneless space through the shroud surface were also evaluated.

Spakovszky [1] had initially shown that an improvement in stable range could be obtained by injecting air through the shroud surface of the vaneless space in a direction that was tangent to impeller rotation.

Skoch [2] tested other variants of shroud-side injection. Significant results were obtained when the injectors were oriented to produce a vaneless space jet that was tangent to the impeller, but traveled in a direction that was opposite to impeller rotation. Results from shroud surface experiments proved to be very promising and showed that both a significant improvement in stable flow range as well as an ability to recover from fully developed surge could be obtained from control actions taken on the shroud surface.

Additionally, it was discovered that obstructions created by bleed tubes inserted into the vaneless space through the shroud surface provided an excellent improvement in stable flow range when the tubes were sealed to prevent bleed. These surge control tubes provided better range improvement than air injection and caused less loss of total pressure in the diffuser. 
In describing the results from shroud-side techniques, Skoch [2] concluded that the observed benefits in diffuser stability came from a reduction in the flow angle of impeller discharge fluid traveling through the vaneless space. Part of the flow angle adjustment was due to an increase in radial velocity resulting from a reduction of effective flow area in the vaneless space that was caused by the injected stream or control-tube. The second part came from a reduction in tangential velocity caused by interaction with the injected jet or tube.

Hub-side injection was tested first in the same series of experiments that explored shroud-side stability control. The hub nozzles were oriented to produce jets that traveled along the vane surfaces into the diffuser passage instead of acting on flow within the vaneless space. Hub-side injection did not produce an improvement in stable flow range with the nozzle orientations that were tested. Pressure measurements collected in the diffuser indicate that injection on the hub surface did not produce the same adjustment in flow angle as shroud-side injection. The trends in diffusion and vane loading were opposite those observed with successful shroud-side techniques, as were the changes in stable flow range of the compressor.

The mere presence of the hub-side injectors did provide a minor improvement in range. That improvement was partially due to a reduction in the pressure variation between diffuser passages, as was reported by Raw [3] who demonstrated surge margin improvements in a conical pipe diffuser by using "porous drillings" to bleed flow from the region of the diffuser throat. Communication of pressure in the current test was through a manifold that connected the injector nozzles.

In addition to the communication noted above, the presence of hub-side injector nozzles provided some resistance to tangential flow in the vaneless space. The results indicate that turning the nozzles toward a radial orientation may have produced a higher level of resistance. Minor improvements in range occurred without any injection at nozzle orientations that were more toward radial and diffusion trends in the diffuser matched those observed with successful shroud side techniques.

While no significant range improvement was demonstrated, results from the hub injection experiments support the conclusions drawn from the successful shroud-side experiments and are therefore reported here. Further, the results suggest that hub injection may have shown an improvement, had the nozzles been oriented to produce a jet that opposed the swirl velocity in the vaneless region of the diffuser.

\section{Nomenclature}

$\begin{array}{ll}P & \text { total pressure } \\ p & \text { static pressure } \\ T & \text { total temperature } \\ T_{5} & \text { total temperature at exit rake plane after correcting for injection } \\ T_{5, \text { measured }} & \text { measured total temperature at exit rake plane } \\ T_{\text {injector }} & \text { total temperature of injector flow } \\ \dot{m}_{\text {ref }} & \text { impeller net inlet corrected mass flow on choked flow segment of pressure rise characteristic } \\ \dot{m}_{\text {surge }} & \text { impeller net inlet corrected mass flow at surge } \\ \dot{m}_{\text {impeller }} & \text { impeller absolute mass flow } \\ \dot{m}_{\text {injector }} & \text { injector absolute mass flow } \\ \pi_{\text {ref }} & \text { stage total pressure ratio at lowest pressure ratio on choked flow segment of pressure rise } \\ \pi_{\text {surge }} & \text { characteristic } \\ \text { stage total pressure ratio at surge } & \text { surge margin, }\left(1-\frac{\pi_{\text {ref }}}{\pi_{\text {surge }}} \bullet \frac{\dot{m}_{\text {surge }}}{\dot{m}_{\text {ref }}}\right) \times 100 \text { percent }\end{array}$




$\begin{array}{ll}\rho U^{2} & \text { impeller dynamic head } \\ \Delta H_{\text {isen }} & \text { isentropic enthalpy rise } \\ \Delta H_{\text {act }} & \text { actual enthalpy rise } \\ \eta & \text { adiabatic efficiency, } \Delta H_{\text {isen }} / \Delta H_{\text {act }} \\ & \\ \text { Measurement Station Subscripts } \\ 0 & \text { upstream plenum } \\ 1 & \text { impeller trailing edge } \\ 2 & \text { diffuser vane leading edge } \\ 3 & \text { diffuser throat } \\ 4 & \text { diffuser exit } \\ 5 & \text { rake plane in diffuser exit passage }\end{array}$

\section{Test Compressor}

The test compressor is an Allison Engine Company design that was scaled up to a flow size of $10 \mathrm{lbm} / \mathrm{s}(4.54 \mathrm{~kg} / \mathrm{s})$ from the original size of $3.655 \mathrm{lbm} / \mathrm{s}(1.658 \mathrm{~kg} / \mathrm{s})$. McKain and Holbrook [4] give complete aerodynamic and mechanical design descriptions, including impeller and diffuser geometries.

The stage (impeller with vane-island diffuser) was designed to produce a pressure ratio of 4:1 at the design mass flow. The standard day corrected speed for the design flow condition is $21,789 \mathrm{rev} / \mathrm{min}$ with an exit tip speed of $1615 \mathrm{ft} / \mathrm{s}(492 \mathrm{~m} / \mathrm{s})$. The mean value of the relative inflow Mach number is 0.69. The impeller contains 15 main blades and 15 splitter blades and has 50 degrees of backsweep from radial at the discharge. The splitter-blade leading edge, located at 20 percent of main blade chord, is offset slightly toward the main-blade suction surface in order to produce an even flow split. Both the main blades and splitter blades are formed from quasi-normal straight-line elements between the hub and tip. The inlet tip diameter is 8.264 in. $(210 \mathrm{~mm})$ and the inlet blade height is $2.501 \mathrm{in} .(64 \mathrm{~mm})$. The exit diameter is $16.986 \mathrm{in.}(431 \mathrm{~mm})$ and the exit blade height is $0.671 \mathrm{in} .(17 \mathrm{~mm})$. All dimensions are for hot conditions at 100 percent of design speed.

The vane-island diffuser contains twenty-four passages. The vane leading edge is at a radius ratio of 1.08 and the mid-pitch of the passage throat is at a radius ratio of 1.10 compared to the impeller exit radius. The diffuser exit is at a radius ratio of 1.68 .

\section{Hub Injection Apparatus}

Cross sections of the centrifugal compressor test-rig, a hub- side injector and the air supply system are shown in figure 1. Measurement stations located upstream of the impeller (Station 0), at the impeller trailing edge (Station 1) and downstream of the diffuser (Station 5) are also shown. One of eight recirculation air pickups, used in a configuration where internal air was supplied to the injectors, is shown in same plane as the downstream (Station 5) measurement location.

\section{Hub-Side Injectors}

Twenty-two wall tangent injector nozzles were installed on the hub side of the diffuser as shown in figure 2. A nozzle was positioned directly upstream of the leading edge of each diffuser vane with the exception of two. Two passages were left without injectors in order to preserve a static pressure array in the semi-vaneless region of the passage. The nozzle positions were manually reset to provide the directional options shown in figure 3. Air was supplied to all of the twenty-two injection nozzles by a 


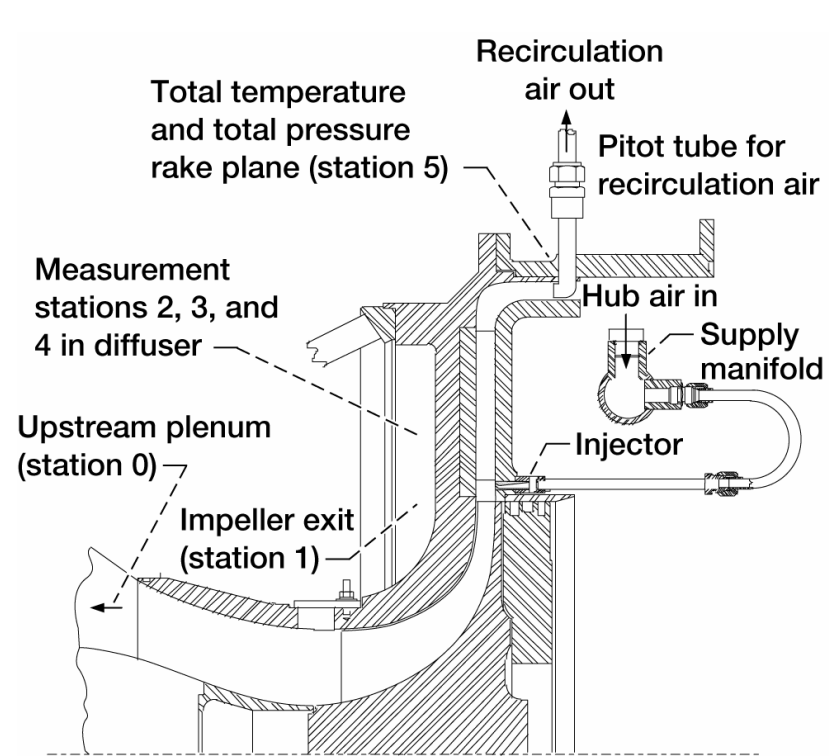

Figure 1.-Cross section of test compressor and air injection apparatus.

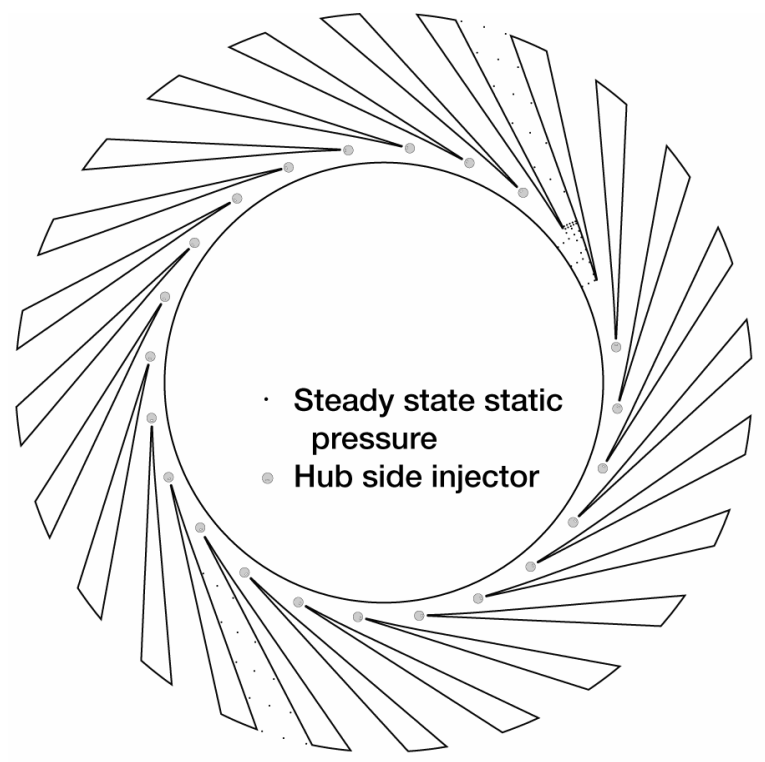

Figure 2.-Diffuser hub instrumentation and injector nozzle locations.

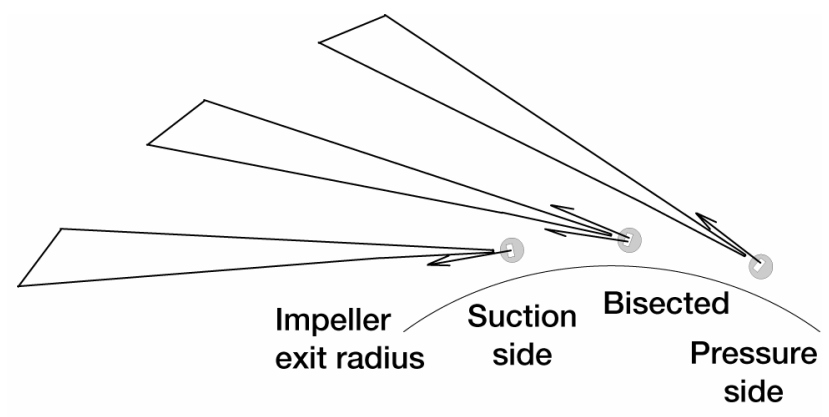

Figure 3.-Hub-side injector nozzle orientations.

circumferential manifold that was inside the test-rig exhaust collector and adjacent to the diffuser hub (fig. 1). Flow area within the air supply system was large compared to the total of throat areas from all nozzles in order to encourage a uniform air supply to each nozzle. The manifold cross-section had an area that was more than five times the total of injector throat areas. The cross section of a single injector supply tube was also more than five times the throat area of a single injector. The manifold was supplied by an external air source or by Pitot tubes located at the diffuser discharge. The nozzles were sized to choke when the total injected flow rate was $0.5 \mathrm{lbm} / \mathrm{s}(0.23 \mathrm{~kg} / \mathrm{s})$ using air at $540{ }^{\circ} \mathrm{R}$.

\section{Test Procedure, Instrumentation}

Compressor stability experiments were completed over a speed range of 60 to 100 percent of design speed and at tip clearances of 2.4, 3.6 and 4.8 percent of exit blade height. Results from tests done at 100 percent of design speed with a tip clearance equal to 2.4 percent of exit blade height are reported here. At each condition, the compressor was throttled to a starting point on the operating characteristic that was near surge and then ramped into surge by closing the throttle slowly at a constant rate. In some 
cases, steady state data were first collected along a complete constant speed characteristic; in others only partial characteristics were obtained.

The flow rate where the compressor surged was determined by noting the flow rate where a significant change occurred in the sound emanating from the compressor indicating the start of a strong surge cycle. In [2] the accuracy of the audible surge indicator was checked against a computed value that was based on a digitized measurement of pressure drop across the main flow orifice. The audible value was found to be within -0.05 and $+0.15 \mathrm{lbm} / \mathrm{s}(-0.023$ and $+0.068 \mathrm{~kg} / \mathrm{s})$ of the computed value. While a digitized measurement of pressure drop was not available for these experiments, the accuracy of the audible surge indicator is assumed to be similar since both experiments were completed during a single entry into the test facility.

The surge flow rate was sensitive to changes in impeller tip clearance. Air injection changed the local metal temperature enough to change the clearance between the impeller trailing edge and the shroud. After arriving at a starting point on the characteristic that was near surge, the flow path dimensions were allowed to adjust to the temperature conditions created by air injection. The tip clearance was then adjusted to its initial value using a unique feature of the test rig that permits controlled axial movement of the impeller during operation. Tip clearance was measured during operation using a high-voltage touchprobe system.

Steady-state static pressure arrays were located in two passages on each of the hub and shroud surfaces. The hub side static pressure arrays are shown in figure 2. Similar arrays were located on the shroud. Also located on the shroud were eight static pressure taps that were evenly distributed about the circumference of the impeller at its trailing edge.

The lack of static pressure measurements in the immediate region of a nozzle prevents a discussion of the localized effect of the nozzle or injected jet on the diffuser flow. However, pressure measurements collected in a region without a nozzle provide a better picture of the overall effect of injection on diffuser performance. Measurements from the static pressure arrays on the hub surface were averaged with similar arrays on the shroud to present a view of changes in the overall character of the diffuser flow field.

Stage total temperature and total pressure rise were determined from measurements collected in the upstream plenum and from rakes located in the discharge channel downstream of the diffuser. The downstream rake plane is marked in figure 1. Six, four-element total pressure rakes and eight, three-element total temperature rakes were located in the downstream plane. Rakes were distributed symmetrically about the twenty-four passages of the diffuser.

Five of the total temperature rakes and three of the total pressure rakes were replaced by Pitot tubes when recirculated air was used to supply injectors. The variation in measurements obtained at downstream rake locations was checked with all rakes installed to estimate the error created by replacing some rakes with Pitot tubes for recirculation experiments. The maximum deviation of measurements from individual rakes compared to the average of all rakes was less than \pm 0.9 percent for total pressure and \pm 0.4 percent for total temperature at injected flow rates of $0.15 \mathrm{lbm} / \mathrm{s}(0.068 \mathrm{~kg} / \mathrm{s})$ or less.

Steady-state data were collected using the test cell data system (Escort System) that records all steadystate pressure, temperature and speed data needed to determine compressor performance. Steady-state measurement uncertainties are pressure $0.1 \mathrm{psi}\left(0.1 \mathrm{~N} / \mathrm{cm}^{2}\right)$, temperature $1{ }^{\circ} \mathrm{R}\left(0.6^{\circ} \mathrm{C}\right)$, mass flow $0.05 \mathrm{lbm} / \mathrm{s}(0.023 \mathrm{~kg} / \mathrm{s})$, and pressure ratio 0.1 percent. The Escort System was also used to collect performance data while ramping toward surge since the throttle was being closed slowly. Data readings were taken at roughly $0.1 \mathrm{lbm} / \mathrm{s}(0.05 \mathrm{~kg} / \mathrm{s})$ flow increments between the ramp starting point and the surge point.

\section{Experimental Results}

The pressure rise characteristics shown in figures 4 through 6 and figures 9 through 11 are results obtained at several injected flow rates for each of the hub nozzle orientations shown in figure 3 . All of the 
hub injection data were obtained with solid plugs installed in the shroud side openings used later for injection and control-tube experiments.

The plus symbols (+) are data from the baseline configuration for each nozzle orientation and were obtained using zero injected flow. The baseline characteristic for the suction-side orientation is also the baseline used to compare shroud-side injection and control-tube techniques in [2].

The other characteristics shown for each nozzle orientation were produced with various levels of air flow injected through the hub nozzles. Some characteristics are complete (choke to surge) and others are only partial as the usual test procedure was to begin at a point close to the surge flow rate of the baseline and then ramp the throttle closed at a constant rate.

The mass flow rates of data shown in figures 4, 9, 10, and 11 have been adjusted to account for flow that was injected into the diffuser since it was injected downstream of the main flow measuring orifice. The uncorrected mass flow entering the compressor inlet was adjusted by adding the uncorrected injection flow rate to it and correcting the sum to inlet conditions. This adjustment is made in order to view the characteristics in terms of flow rate entering the diffuser while treating that flow as if it had been processed by the entire stage. Axis titles indicate "Net" flow where an adjustment was made.

The final data point on each characteristic is at the flow rate determined from the audible surge indicator, also adjusted for injection. Mass flow at the surge point was determined from the mass flow shown on a steady state rig performance display when the audible surge indicator was heard. Since it was difficult to observe both mass flow and pressure ratio simultaneously, the pressure ratio at surge was estimated using the mass flow at surge and first or second order curve fits of the last three to six steady state data points preceding surge. An estimate of surge pressure ratio from steady state data is required because there were no high response transducers in the downstream rake plane to provide a direct measurement of total pressure at surge.

The characteristics of figures 4 through 9 show that hub injection did not improve the stable flow range of the compressor and in most cases caused a decrease. Surge margins based upon the first (ref) and final (surge) points of each full characteristic are shown in the legends of each figure where surge margin is defined as:

$$
S M=\left(1-\frac{\pi_{\text {ref }}}{\pi_{\text {surge }}} \cdot \frac{\dot{m}_{\text {surge }}}{\dot{m}_{\text {ref }}}\right) \times 100 \text { percent and } \pi=\frac{P_{5}}{P_{0}}
$$

This definition of surge margin isolates the computation to an individual characteristic by comparing the performance at surge to performance at the lowest pressure rise on the choked flow segment of the characteristic. Injection from an external source will change the position of the overall characteristic by producing offsets in through flow and pressure ratio relative to a normal operating line. The constant speed definition of surge margin removes the influence of overall offsets if injector flow rate is held constant and each characteristic is started at the same throttle position.

\section{Diffuser Hub Suction-Side Injection}

The pressure rise characteristics shown in figure 4 are results obtained at several injected flow rates when the hub nozzles were oriented toward the vane suction surface as shown in figure 3 . A comparison of surge margins given in the legend of figure 4 shows that surge margin decreased as injected flow was increased in this case, moving from 36.7 at zero injection to 34.3 at the maximum injected flow rate of $0.67 \mathrm{lbm} / \mathrm{s}(0.304 \mathrm{~kg} / \mathrm{s})$. 


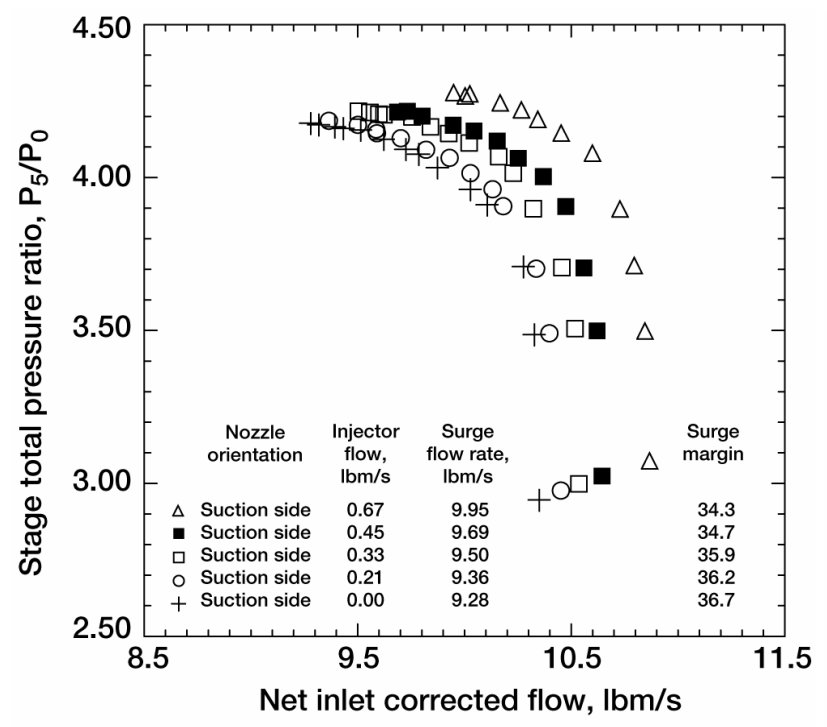

Figure 4.-Stage total pressure ratio vs. net flow entering the diffuser corrected to inlet conditions at design speed and 2.4 percent tip clearance with hub suctionside injection.

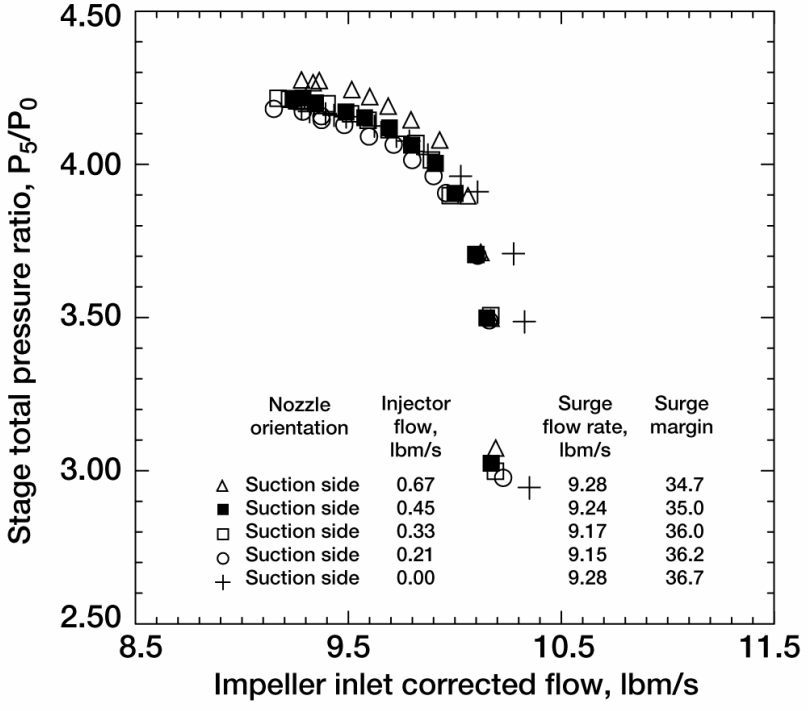

Figure 5.-Stage total pressure ratio vs. impeller inlet corrected flow at design speed and 2.4 percent tip clearance with hub suction-side injection.

The characteristics of figure 4 have been adjusted using the injector flow rate and appear to move along a constant throttle line as if speed was increasing. Speed was not increasing in this case, but air supplied from an external source was injected into the diffuser in a direction that was nearly tangential to impeller rotation. Some increase in pressure ratio resulting from the total pressure of the externally supplied injection flow is reflected in an apparent increase in compressor speed that is implied by the relative positions of the characteristics.

High injection flow rates on the hub surface did not cause the same reduction in measured impeller inlet flow that was observed in shroud-side experiments [2]. The characteristics of figure 4 moved significantly to the right of the baseline when injected mass flow adjustments were added to the measured inlet flow.

Figures 5 through 8 show results from hub suction-side injection plotted using only the measured flow rate at the impeller inlet. Only small through flow reductions are seen along the choked flow segments of the characteristics in figure 5 , even at the highest injector flow rate.

The diffuser was able to swallow most of the additional airflow introduced by injection, preventing a substantial reduction in the flow rate entering the impeller. Part of the injected flow may have filled a blockage within the diffuser passage without creating substantial additional blockage itself.

\section{Stage Efficiency: Suction-Side Injection}

Impeller performance was influenced by at least some portion of the injected flow. Figure 6 shows impeller pressure ratio plotted against unadjusted impeller inlet flow. Impeller pressure ratio increased at a given mass flow as injector flow rate increased, indicating that injection was creating backpressure on the impeller. The impeller pressure ratio at surge increased from 2.69 on the baseline characteristic to 2.72 when injected flow rate was increased from zero to $0.67 \mathrm{lbm} / \mathrm{s}(0.3 \mathrm{~kg} / \mathrm{s})$. 


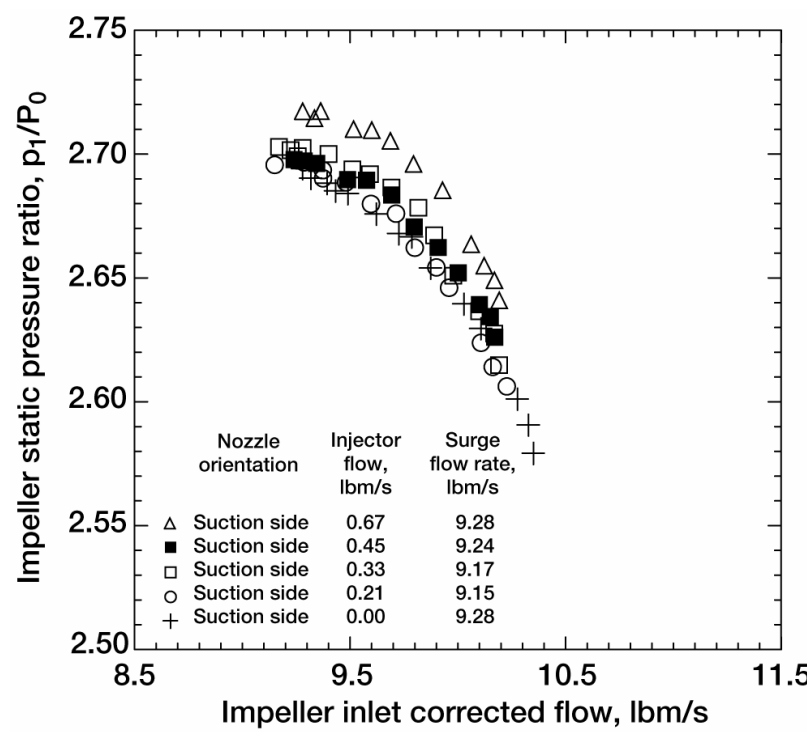

Figure 6.- Impeller static-total pressure ratio vs. impeller inlet corrected flow at design speed and 2.4 percent tip clearance with hub suction-side injection.

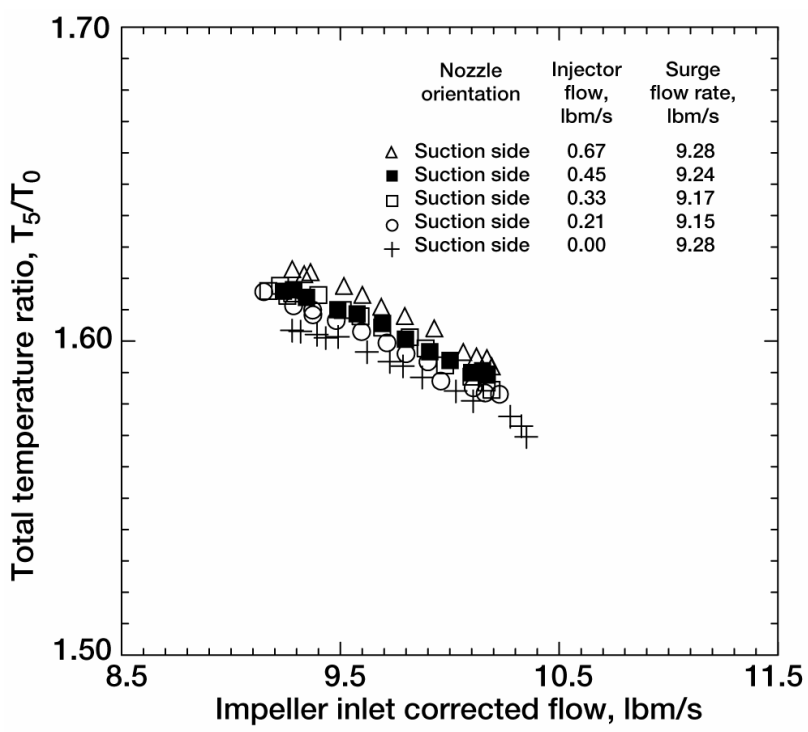

Figure 7.-Impeller total temperature ratio vs. impeller inlet corrected flow at design speed and 2.4 percent tip clearance with hub suction-side injection.

Impeller work input also increased with injection. Stage total temperature ratio is shown in figure 7 for each injector flow rate. Total temperature measurements were corrected to account for external air injection at a total temperature that differed from the local flow. The following correction was applied to the measured total temperature:

$$
T_{5} \dot{m}_{\text {impeller }}=T_{5 \text { measured }}\left(\dot{m}_{\text {impeller }}+\dot{m}_{\text {injector }}\right)-T_{\text {injector }} \dot{m}_{\text {injector }}
$$

Stage efficiency is shown in figure 8. Similar levels of efficiency were maintained at the open throttle condition. The increase in work input by the impeller was not matched by a proportional increase in measured total pressure ratio when through flow was reduced, however, even though total pressure enhancement by flow entering the diffuser from an external source was still present. Efficiency decreased at low through flow rates as a result.

\section{Adjustments to Measured Inlet Flow}

A comparison of surge margins computed for the corresponding characteristics in figures 4 and 5 shows that adjusting the measured inlet flow rate did not substantially change the result. The differences in surge margin between the legends of each figure result from adding a constant to both the numerator and denominator of equation (1) when the injector flow rate adjustment is made.

The flow rate entering the diffuser is the sum of the impeller inlet and injected flow rates. This is true even when recirculation is used to supply the injectors. Measured impeller inlet flow rates should be adjusted in all cases where injection is used in order to establish a consistent basis for comparisons between different injection rates or injector locations.

Surge margin can be computed and compared when full characteristics are available. This is not the case when working with partial characteristics. The only indication of improved surge margin, in that case, is whether the surge point on the characteristic is at equal or higher pressure ratio and at a lower flow rate. Failing to correct the data for injected flow would give a false indication of flow range improvement. 


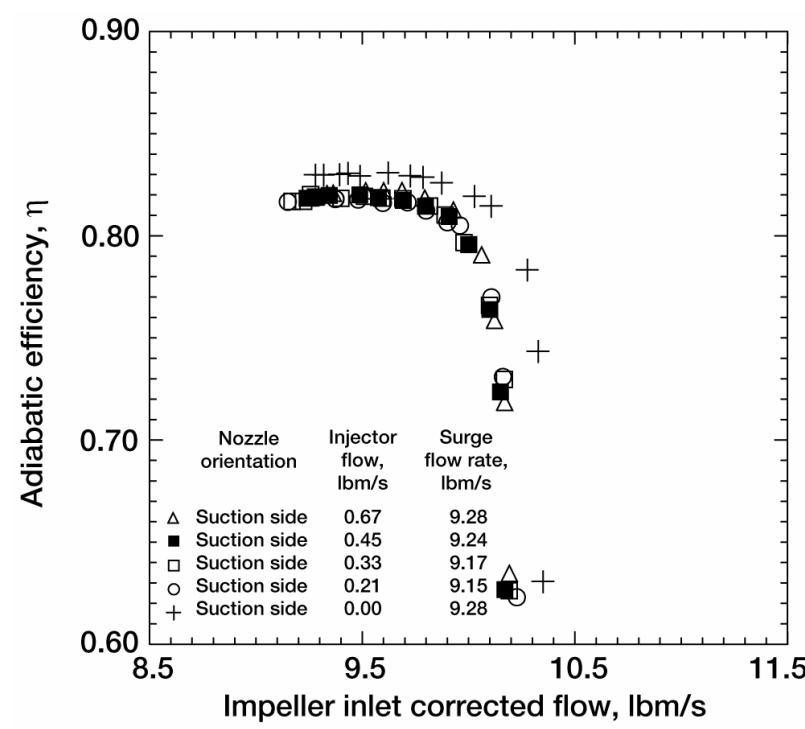

Figure 8.-Stage adiabatic efficiency vs. impeller inlet corrected flow at design speed and 2.4 percent tip clearance with hub suction-side injection.

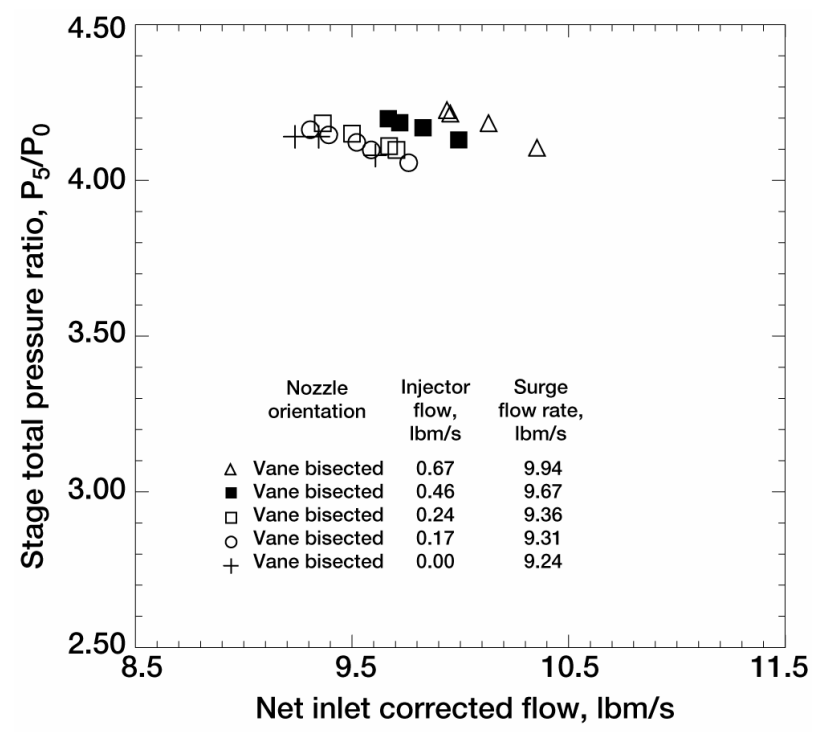

Figure 9.-Stage total pressure ratio vs. net flow entering the diffuser corrected to inlet conditions at design speed and 2.4 percent tip clearance with hub vanebisected injection.

\section{Vane-Bisected Injection and Pressure-Side Injection}

Stage total pressure ratio vs. net inlet corrected flow is shown in figure 9 for several injected flow rates using the vane-bisected orientation. Data from this configuration were collected only for partial characteristics and surge margin was not computed. However, there is no indication of any improvement in stable flow range from the data shown. The partial vane-bisected characteristics behave in a similar fashion to those from the suction-side configuration, where they appear to indicate increasing speed.

Figure 10 shows stage total pressure vs. net inlet corrected flow for the pressure-side configuration. A very small improvement in flow range may be indicated in data from the lowest injected flow rate of $0.05 \mathrm{lbm} / \mathrm{s}(0.023 \mathrm{~kg} / \mathrm{s})$. The pressure ratio of the surge point on this characteristic was estimated from a curve fit. The pressure ratio of the point immediately ahead of surge was measured and since the pressure ratio there did not fall below that of the baseline characteristic, a small improvement in surge margin is implied for this injector flow rate. However, the remaining results from the pressure-side configuration do not indicate that there was any improvement in flow range as the injected flow rate was increased.

Figure 11 shows results from the pressure-side orientation using injection air that was supplied from within the compressor flow path. The Pitot style pickups shown in figure 1 were used to collect air from the diffuser exit passage which was then delivered to the hub injectors. Supply pressure was limited to the velocity head that was recovered in the diffuser and by the pickup, so the injected flow rates tested were lower than those used with an external air supply.

Lower injection rates and internal air did not make a significant difference in the performance of the pressure-side configuration as no significant improvement in flow range is generally seen in this case either. There does appear to be a small improvement in pressure ratio for the injector flow rates above $0.1 \mathrm{lbm} / \mathrm{s}$ in figure 11 and surge occurred at through flow rates nearly equal to the baseline curve. The pressure-side configuration with internal air may have provided a small, but insignificant, improvement in surge margin. 


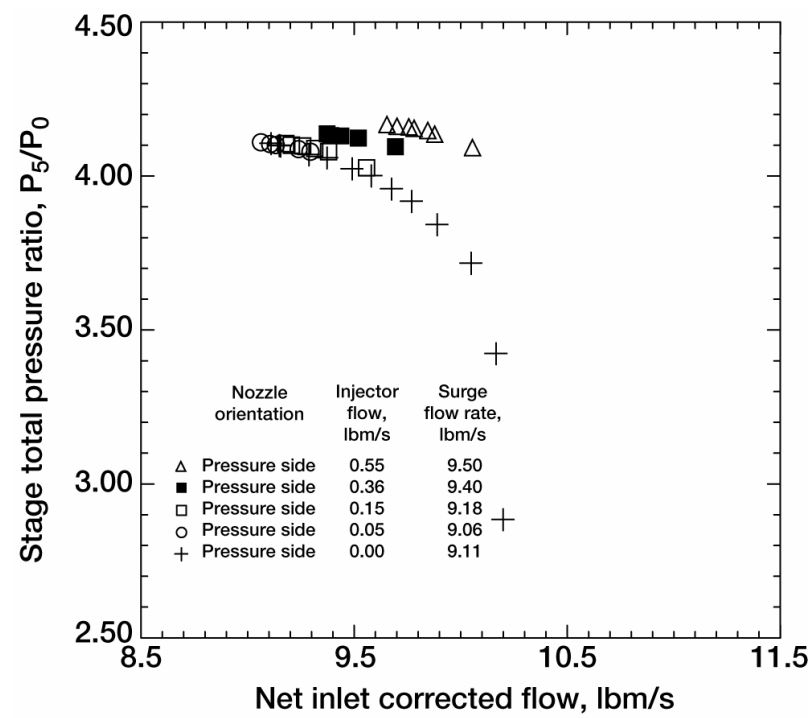

Figure 10.-Stage total pressure ratio vs. net flow entering the diffuser corrected to inlet conditions at design speed and 2.4 percent tip clearance with hub pressure-side injection.

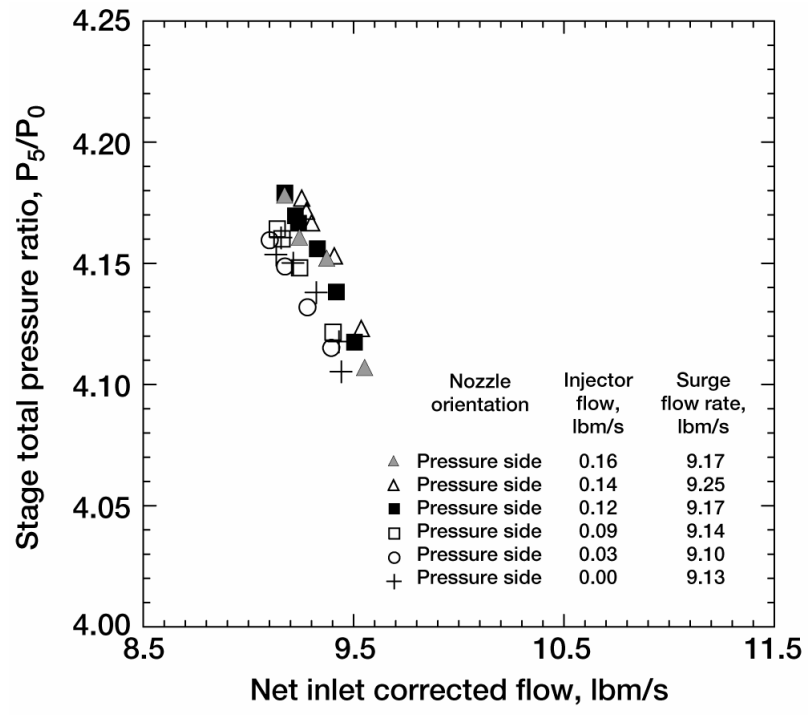

Figure 11.-Stage total pressure ratio vs. net flow entering the diffuser corrected to inlet conditions at design speed and 2.4 percent tip clearance for the recirculation case of pressure-side injection.

\section{Stage Efficiency: Vane-Bisected and Pressure-Side Injection}

Efficiency plots are not shown for the vane-bisected and pressure-side orientations since these, like the suction-side orientation, did not produce the desired effect of flow range improvement. The trends in total temperature ratio and efficiency were similar to those shown in figures 7 and 8 for the suction-side nozzle orientation. Stage total temperature ratio increased faster than total pressure ratio leading to slightly lower stage efficiencies. On average, peak efficiencies for the vane-bisected and pressure-side orientations were about one point lower for the cases with injection compared to the zero injection case and this is about equal to the peak efficiency loss of the suction-side configuration with injection.

\section{Nozzle-Only Comparison}

In the discussion above, compressor stability at various hub injection rates for each nozzle orientation was compared to the performance at zero injection for the same orientation. None of the hub injector configurations tested showed a notable improvement in stable flow range or surge margin when injection was turned on or as the injected flow rate was increased. However, there was a small difference in the flow range and surge margin between the zero injection cases of each nozzle orientation.

Figure 12 compares the zero injection characteristics of the suction-side, vane-bisected and pressureside nozzle orientations. No adjustment to the measured through flow rate was necessary since injection was not in use. The figure shows that there was a tendency toward improved flow range as the injector orientation was turned clockwise from the suction-side orientation to the pressure-side. Surge margin computed for the full characteristics (suction-side and pressure-side) bears this out as surge margin increased from 36.7 when the nozzle was oriented toward the suction side of the vane to 37.3 when it was oriented toward the pressure side. While surge margin was not computed for the vane-bisected configuration, its orientation was between the other two and the vane-bisected results in figure 12 also lie between the results from the suction-side and pressure-side orientations. 


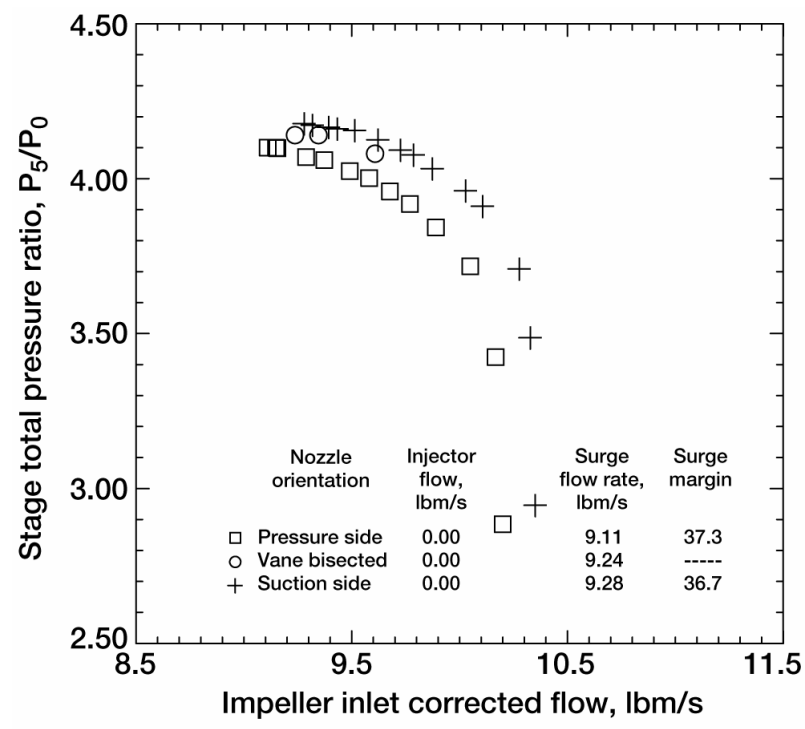

Figure 12.-Stage total pressure ratio at design speed and 2.4 percent tip clearance for the zero injection cases of suction-side, vane-bisected and pressureside nozzle orientations.

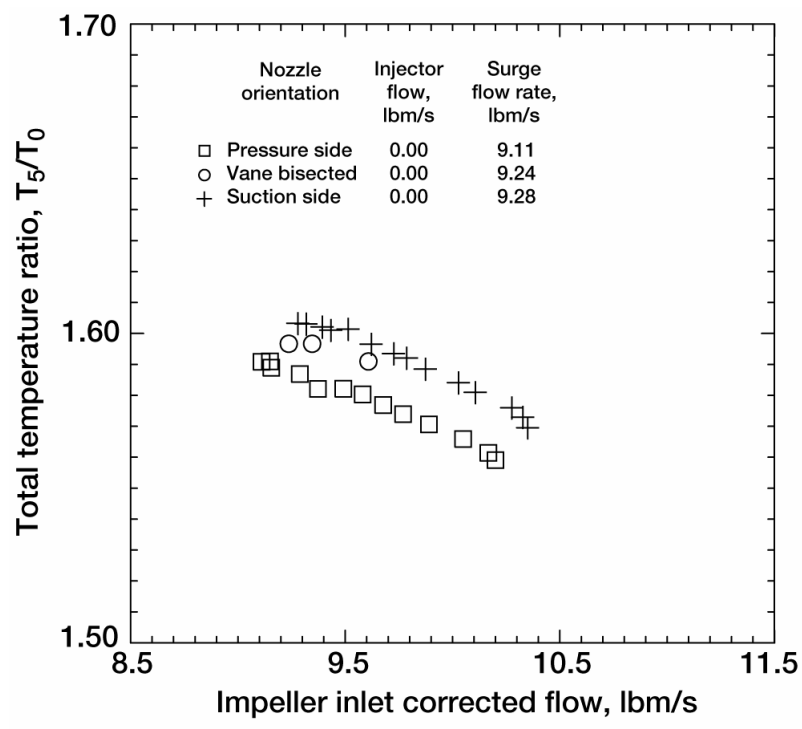

Figure 13.-Stage total temperature ratio at design speed and 2.4 percent tip clearance for the zero injection cases of suction-side, vane-bisected and pressure-side nozzle orientations.

The difference in surge flow rates between the three orientations shown in figure 12 are minor and lie within the error band stated earlier. However, the differences in nozzle orientation were also minor so small changes in surge flow rate are not unexpected. Confidence increases when measurements collected within the diffuser are considered (later) since the observed trends in diffuser performance are similar to those observed in [2] where the improvements in flow range were much greater.

\section{Stage Efficiency: Nozzle-Only Configurations}

Air injection into the diffuser passage caused a small increase in backpressure on the impeller and a corresponding increase in work input by the impeller. The Nozzle-Only data show the opposite effect, less impeller loading as the nozzles were turned toward a more radial orientation.

Figure 13 shows the stage total temperature ratio at each orientation. Turning the nozzles toward the pressure-side orientation resulted in less total temperature rise over the full range of through flow. The total temperature ratio characteristics in figure 13 show a step reduction in temperature ratio between the suction and pressure-side nozzle orientations, while maintaining nearly the same slope as the compressor was throttled. A reduction of impeller work input is also reflected in the reduced impeller pressure ratio seen in figure 14.

Flow resistance or blockage created by the hub nozzles must have altered the span-wise velocity profile of fluid discharging from the impeller. The exact mechanism is not known but the result was either an increase in impeller through-flow velocity, or an increase in slip at the tailing edge. Whatever the mechanism, it did not result in a loss of total pressure. Stage efficiency, figure 15, was maintained at each hub nozzle orientation. The reduction in stage total pressure ratio seen in figure 12 was due to reduced work input by the impeller and was not caused by total pressure loss in the diffuser. 


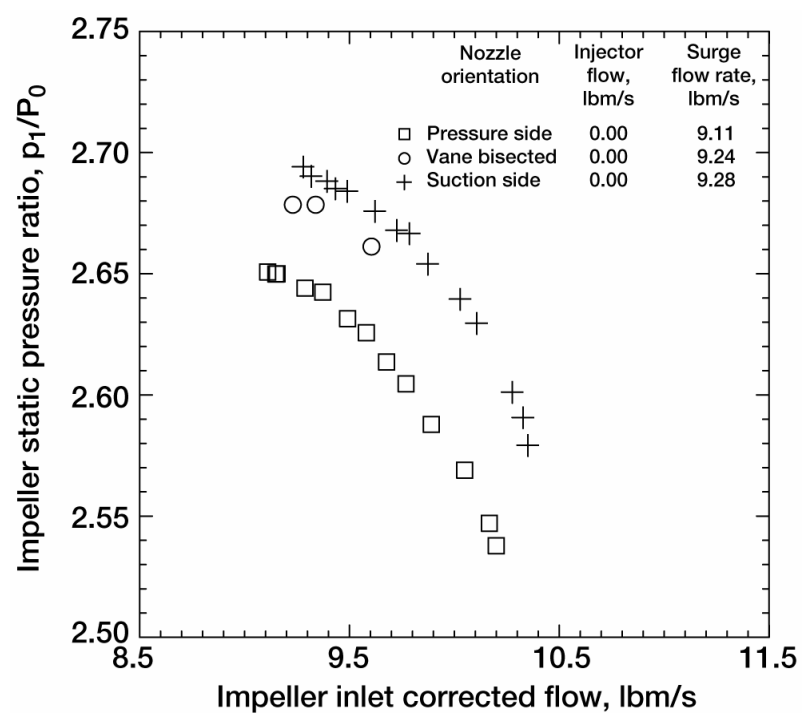

Figure 14.-Impeller static-total pressure ratio vs. impeller inlet corrected flow at design speed and 2.4 percent tip clearance for the zero injection cases of suction-side, vane-bisected and pressure-side nozzle orientations.

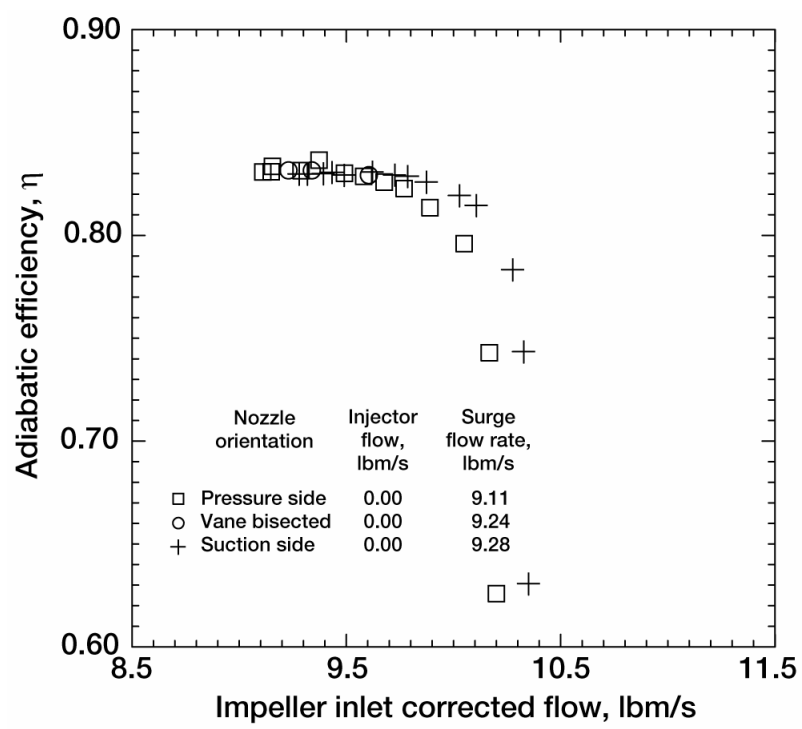

Figure 15.-Stage adiabatic efficiency at design speed and 2.4 percent tip clearance for the zero injection cases of suction-side, vane-bisected and pressureside nozzle orientations.

\section{Diffuser Performance}

In reporting results obtained from experiments done on the shroud endwall of the diffuser vaneless space, Skoch [2] concluded that stable flow range improvements provided by injection and control-tubes were due to a reduction in flow angle entering the diffuser vane row. The conclusion was supported by evidence of reduced diffusion across the vaneless and semi-vaneless regions of the diffuser and by a reduction of loading on both the hub and shroud surfaces of the diffuser vane leading edge. If the pressure-side orientation at zero injection did enhance stability then some indication of reduced diffusion and vane loading should be found in measurements collected in the diffuser.

Figures 16 and 17 show diffusion across the vaneless and semi-vaneless regions of the diffuser, respectively, at each of the three hub nozzle orientations. Pressure recovery decreased in the vaneless region as the compressor was throttled for all orientations. However, the decrease was greater for the vane-bisected orientation and still greater for the pressure-side orientation. Vaneless space pressure recovery decreased to a minimum and then began to increase which is the same effect as created by shroud-side techniques that provided good range improvement. The reason for this effect is discussed later.

Pressure recovery in the semi-vaneless space is shown in figure 17. Pressure recovery measurements from the shroud- side experiments [2] showed that diffusion across this region was reduced, at a given through flow, by the successful techniques. Figure 17 shows similar behavior from the hub nozzle orientations that improved flow range.

Figure 18 and 19 show pressure loading at the leading edge of a diffuser vane. Here, the comparison to shroud-side techniques is not quite as strong. Loading at the shroud surface of the vane (fig. 18) was reduced for a given mass flow but it remained fairly constant at the hub (fig. 19). However, the increase in surge margin between the tangentially oriented suction-side nozzle configuration and the pressure-side configuration was not as significant as the increase produced by shroud-side techniques. Therefore, it is not surprising that the changes in vane leading edge loading are also not as strong. 


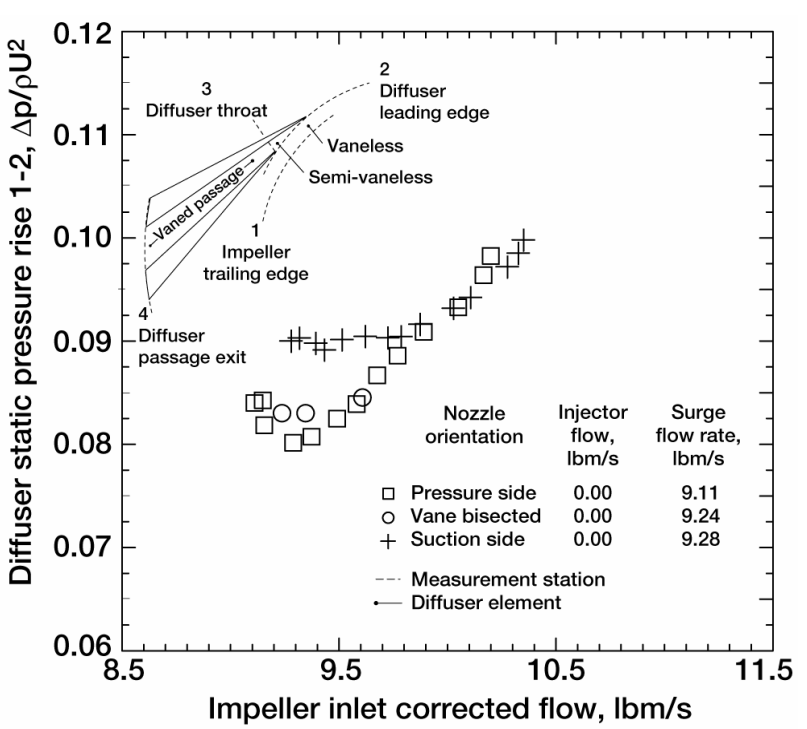

Figure 16.-Static pressure rise in the diffuser vaneless space at design speed and 2.4 percent tip clearance for the zero injection cases of suction-side, vanebisected and pressure-side nozzle orientations.

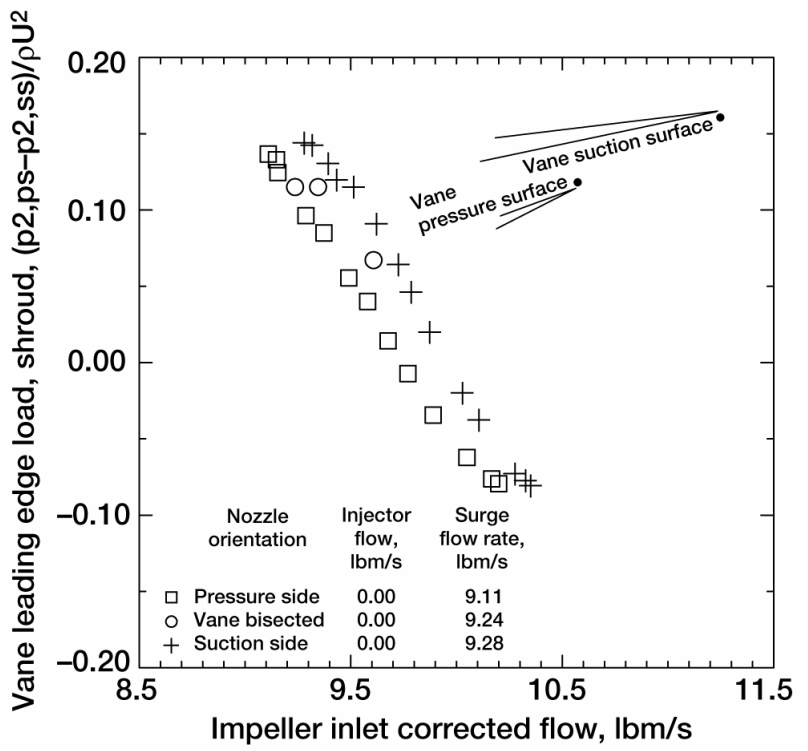

Figure 18.-Diffuser vane leading edge loading on the shroud surface for the zero injection cases of suctionside, vane-bisected and pressure-side nozzle orientations.

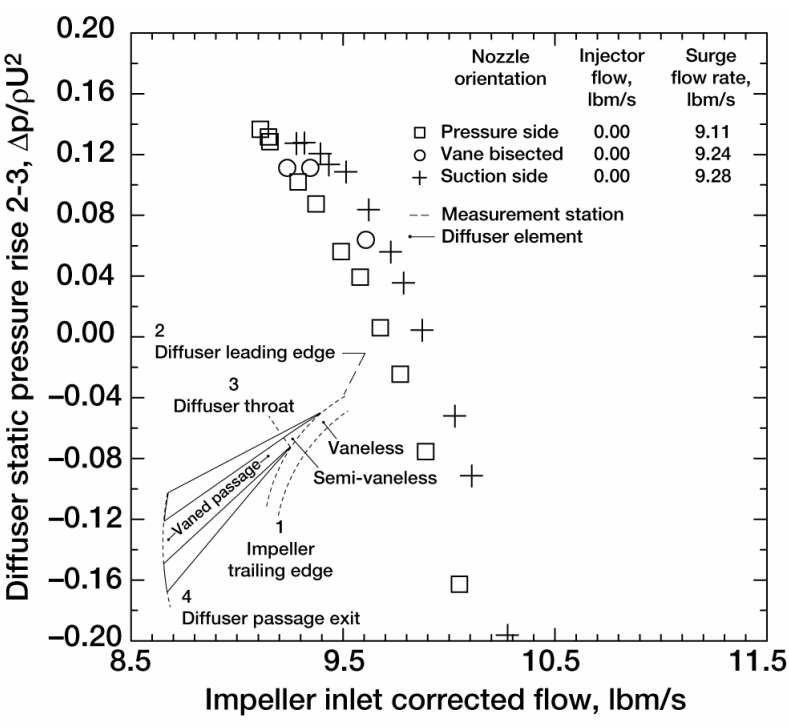

Figure 17.-Static pressure rise in the diffuser semivaneless region at design speed and 2.4 percent tip clearance for the zero injection cases of suction-side, vane-bisected and pressure-side nozzle orientations.

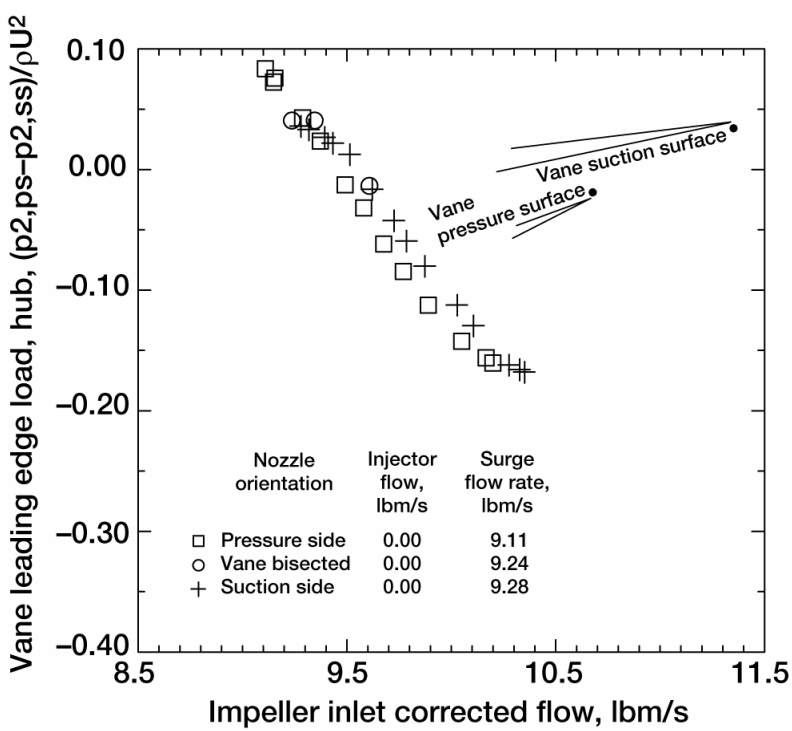

Figure 19.-Diffuser vane leading edge loading on the hub surface for the zero injection cases of suctionside, vane-bisected and pressure-side nozzle orientations.

The fact that loading decreased at the shroud surface instead of at the hub, where the nozzles were located, is most likely due to a shifting of through-flow toward the shroud surface as was noted earlier.

Examples of diffuser performance were not shown for the cases where injection was used. In every case, behavior in diffuser was opposite that which has been described above. Diffusion in the vaneless and semi-vaneless regions increased at a given through flow as compared to the zero injection case for each orientation. The increase was roughly in proportion to the injected flow rate. Vane leading edge loading also trended in a direction opposite to that which is needed for improved stability. Leading edge loading increased at a given compressor through flow as injected flow rate was increased. 


\section{Vaneless Space Pressure Recovery Profile}

As the compressor is throttled to lower flow rates, pressure recovery in the vaneless space (fig. 16) follows a pattern of declining pressure recovery followed by a relatively rapid increase.

The declining portion of the pressure recovery profile seen in figure 16 is caused by an increasing interaction of tangential velocity with an obstruction in the vaneless space created by either a physical obstruction or an air jet that interacts with flow discharging from the impeller. As the compressor is throttled the direction of impeller discharge flow becomes more tangential and the interaction with an obstruction in the vaneless space causes both a loss of tangential velocity and a turning of the absolute velocity vector toward a radial direction.

Eventually, the maximum interaction occurs as the absolute velocity vector becomes directly opposed to the obstruction and the minimum in pressure recovery occurs. As throttling continues and the absolute velocity vector at the impeller exit continues to move toward a tangential direction, fluid discharging from the impeller eventually begins to be forced into the space between the impeller trailing edge and the obstruction. At this point the tangential velocity component within the vaneless space accelerates and diffusion resumes.

Spakovszky [1] reported an improvement in compressor range provided by tangential injection into the diffuser vaneless space through the shroud surface. Air injection was in the direction of impeller rotation and caused the tangential velocity along the shroud surface to increase. The result was an increase in effective area ratio between the impeller exit and diffuser leading edge radius that improved diffusion across the shroud surface of the vaneless space. The same effect is eventually produced by obstructions in the vaneless space with the difference being that it occurs later, after the flow turning and interaction losses have already taken place.

Evidence to support this conclusion can be found in results from techniques that were previously tested on the shroud endwall [2]. Figure 20 is reproduced from [2] and shows the vaneless space pressure recovery for the various control-tube and injection techniques tested on the shroud endwall. Figure 21 shows one of seven control-tubes that were installed in the test rig.

The vaneless space pressure recovery characteristics from shroud-side experiments (fig. 20) have the same profile as seen in figure 16 , decreasing then increasing for all configurations except one which was.

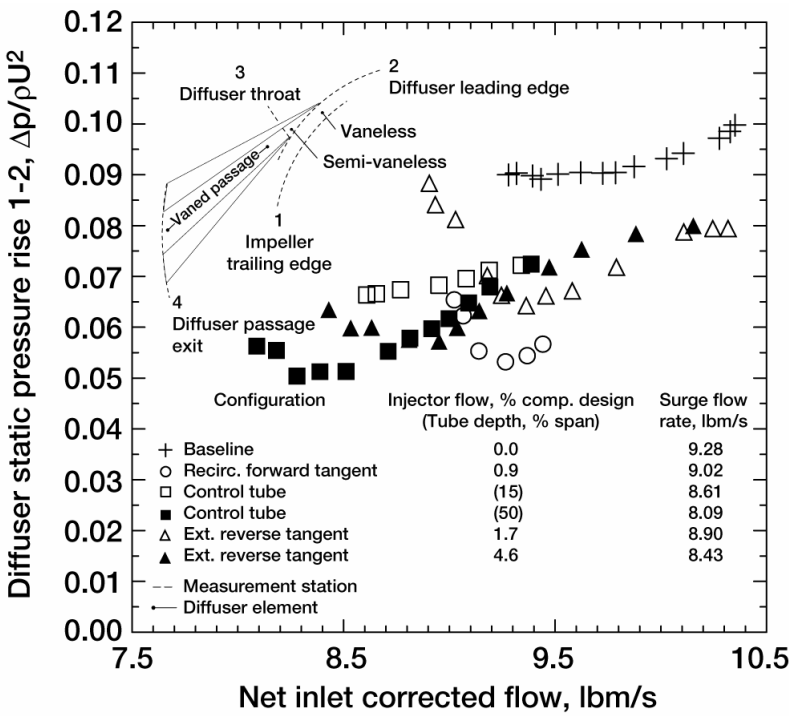

Figure 20.-Static pressure-rise in the diffuser vaneless space at design speed and 2.4 percent tip clearance produced by range improvement techniques applied to the shroud surface, reproduced from [2].

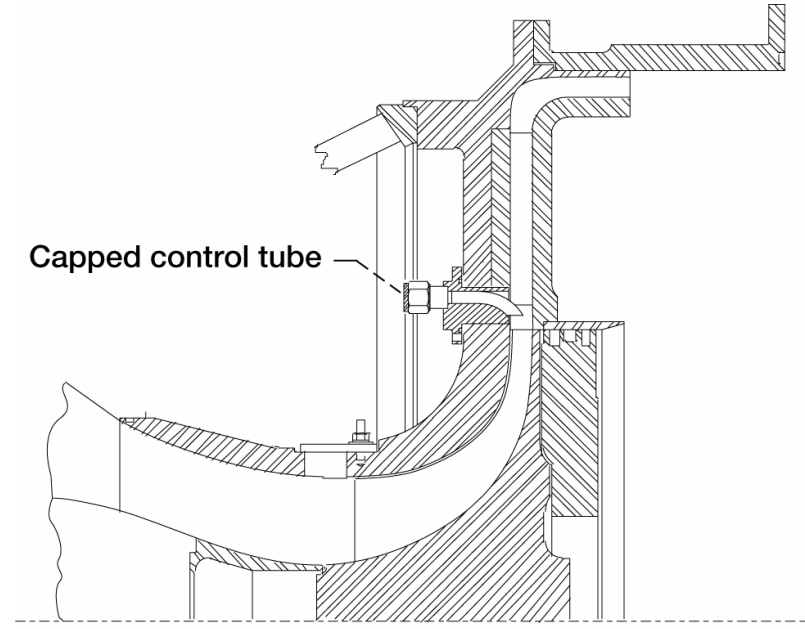

Figure 21.-Cross section of test compressor showing control tube configuration tested in [2]. 


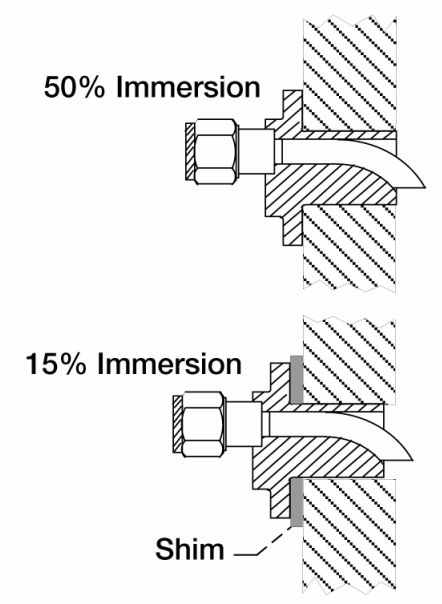

Figure 22.-Control tube immersions previously tested on the shroud surface [2]. Two immersions were achieved by placement and removal of a shim.

the 15 percent-control-tube configuration (open squares). This configuration was the only one to show a continued decrease in pressure recovery as the compressor was throttled to surge without reaching a minimum and subsequent increase in pressure recovery

The reason for that behavior can be found in figure 22 which shows how the two immersions tested, 15 percent and 50 percent, were implemented. The un-shimmed control-tube was located at a depth within the vaneless space that was equal to 50 percent of the local span. The carrier plug surrounding the tube was then shimmed to achieve a 15 percent immersion. Movement of the carrier plug caused the plug surface that was previously flush with the flow path to move away from the flow path and increase the open volume surrounding the tube. The 15 percent-control-tube configuration did not produce the eventual increase in vaneless space diffusion because there was more flow area between the tube and the impeller trailing edge. Conversely, the 50 percent-control-tubed did not have the extra flow area and, therefore, did produce the pattern of decreasing then increasing diffusion as the compressor was throttled.

\section{Hub Surface Vaneless Space Obstruction}

Two orientations of the diffuser hub injector nozzles, used without injection, have been shown to have an effect on diffuser performance that is similar to the obstruction (control-tube) technique that was previously tested on the shroud surface.

The question of how an obstruction was created by hub injection nozzles is now addressed. All of the nozzles were seated against machined surfaces and the nozzle surface adjacent to the vaneless space was flush with the endwall surface. The different orientations were obtained by rotating the existing nozzles and then reseating them against the same machined surfaces. If there was any error in the match between the two flow-path surfaces it did not change for the various orientations that were tried.

The only obvious difference between the three orientations was the angle between the flat side of the injector opening and the tangential velocity vector of fluid traveling through the vaneless space. Figure 23 shows a sketch of the nozzle passage (not to scale) and the relative orientations of the three injector positions to the tangential component of velocity in the vaneless space.

When the nozzles were set to inject air on the suction side of the diffuser vanes the side wall of the injector opening was parallel to the tangential velocity vector of fluid within the vaneless space. As the nozzles were turned toward the other two orientations the flat side wall moved toward a radial orientation and began to oppose the tangential component of velocity in the vaneless space flow. The hub nozzles became an obstruction that was smaller in scale but still similar in effect to the control tubes previously employed on the shroud surface. 


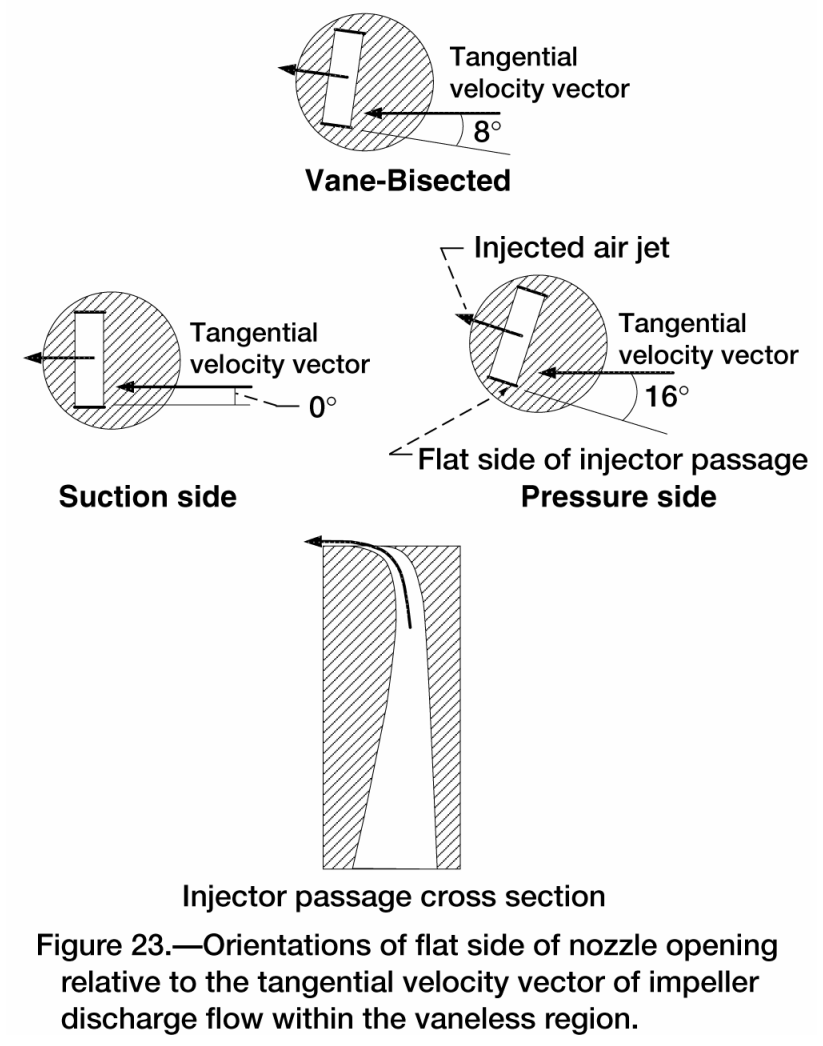

\section{Summary}

The benefits to centrifugal compressor stability provided by injecting air adjacent to the diffuser vanes through the hub surface of the diffuser were evaluated. Injectors were located just upstream of the leading edge of 22 diffuser vanes in a diffuser having a total vane count of 24 . Three nozzle orientations were tested that concentrated air injection on the suction side of the vanes, on both the suction and pressure sides, and finally on the pressure side. Jets of air injected in this fashion did not provide any notable improvement in the stable flow range of the compressor or in surge margin.

Increasing the total injected flow rate did not have much effect on flow rate entering the impeller inlet. While a slight decrease was noted in flow at the inlet, it was not in proportion to additional flow being injected into the diffuser. A separation or blockage in the diffuser passage may have been responsible for the observed behavior. Injection air simply filled the separated region but did not create additional blockage downstream of the throat.

A small improvement in stability occurred due to nozzle orientation alone and it occurred without the use of air injection. Surge margin improved by a small amount as the injector nozzles were turned from the suction-side to pressure-side orientations and stage efficiency was maintained. The suction-side position pointed the injector opening in a direction that was aligned with the tangential component of fluid flow in the vaneless space. As the nozzles were rotated toward the pressure-side orientation, a flat side of the injector passage became opposed to the tangential component of flow in the vaneless space and the nozzles became obstructions to the flow.

Diffuser data from the nozzle configurations without injection were compared to data obtained in earlier experiments [2] where control-tubes inserted through the shroud surface were found to improve stability. A comparison of the change in diffuser performance between the various hub nozzle orientations and different immersions of the control tubes found that both had a similar effect. The magnitude of 
changes in diffuser performance caused by the nozzles was lower than that observed using control-tubes, but the obstruction presented by a hub nozzle was also lower.

The results of hub injection experiments and the comparison to successful shroud-side results suggest that successful stability improvement techniques must act upon flow within the vaneless space of the diffuser. The hub nozzles were located just upstream of the leading edges of the diffuser vanes. The injected air jets traveled immediately into the diffuser passage which proved to be an ineffective means to improve stability, at least in this compressor.

The nozzles alone affected the diffuser in a way that was similar to the control-tube technique previously implemented on the shroud surface and did provide a minor improvement in surge margin.

It stands to reason that if the hub nozzles had been oriented to inject flow in a tangential direction that was opposite to impeller rotation they may have provided a range improvement similar to the reversetangent injection that was previously demonstrated on the shroud surface [2].

\section{References}

[1] Spakovszky, Z.S., 2002, "Backward Traveling Rotating Stall Waves in Centrifugal Compressors," ASME Turbo Expo, Amsterdam, The Netherlands, ASME Paper No. GT-2002-2039.

[2] Skoch, G.J., 2003, "Experimental Investigation of Centrifugal Compressor Stabilization Techniques," ASME Journal of Turbomachinery, 125, pp.704-713.

[3] Raw, J.A., 1986, "Surge Margin Enhancement by a Porous Throat Diffuser," Canadian Aeronautics and Space Journal, 32, (1), pp. 54-60.

[4] McKain, T.F., and Holbrook, G.J., 1982, "Coordinates for a High Performance 4:1 Pressure Ratio Centrifugal Compressor," NASA CR-204134. 
Public reporting burden for this collection of information is estimated to average 1 hour per response, including the time for reviewing instructions, searching existing data sources, gathering and maintaining the data needed, and completing and reviewing the collection of information. Send comments regarding this burden estimate or any other aspect of this collection of information, including suggestions for reducing this burden, to Washington Headquarters Services, Directorate for Information Operations and Reports, 1215 Jefferson Davis Highway, Suite 1204, Arlington, VA 22202-4302, and to the Office of Management and Budget, Paperwork Reduction Project (0704-0188), Washington, DC 20503.

\begin{tabular}{|l|l|l}
\hline 1. AGENCY USE ONLY (Leave blank) & $\begin{array}{c}\text { 2. REPORT DATE } \\
\text { October } 2004\end{array}$ & $\begin{array}{r}\text { 3. REPORT TYPE AND DATES COVERED } \\
\text { Technical Memorandum }\end{array}$ \\
\hline
\end{tabular}

4. TITLE AND SUBTITLE 5. FUNDING NUMBERS

Experimental Investigation of Diffuser Hub Injection to Improve Centrifugal Compressor Stability

WBS-22-708-28-03

6. AUTHOR(S) 1L161102AF20

Gary J. Skoch

7. PERFORMING ORGANIZATION NAME(S) AND ADDRESS(ES)

8. PERFORMING ORGANIZATION REPORT NUMBER

National Aeronautics and Space Administration

John H. Glenn Research Center at Lewis Field

E-14677

Cleveland, Ohio 44135-3191

9. SPONSORING/MONITORING AGENCY NAME(S) AND ADDRESS(ES)

National Aeronautics and Space Administration

Washington, DC 20546-0001

and

U.S. Army Research Laboratory

Adelphi, Maryland 20783-1145

10. SPONSORING/MONITORING AGENCY REPORT NUMBER

NASA TM-2004-213182

ARL-TR-3158

GT2004-53618

11. SUPPLEMENTARY NOTES

Reponsible person, Gary J. Skoch, organization code 5810, 216-433-3396.

12a. DISTRIBUTION/AVAILABILITY STATEMENT 12b. DISTRIBUTION CODE

Unclassified - Unlimited

Subject Category: 07

Distribution: Nonstandard

Available electronically at http://gltrs.grc.nasa.gov

This publication is available from the NASA Center for AeroSpace Information, 301-621-0390.

13. ABSTRACT (Maximum 200 words)

Results from a series of experiments to investigate whether centrifugal compressor stability could be improved by injecting air through the diffuser hub surface are reported. The research was conducted in a 4:1 pressure ratio centrifugal compressor configured with a vane-island diffuser. Injector nozzles were located just upstream of the leading edge of the diffuser vanes. Nozzle orientations were set to produce injected streams angled at $-8,0$ and +8 degrees relative to the vane mean camber line. Several injection flow rates were tested using both an external air supply and recirculation from the diffuser exit. Compressor flow range did not improve at any injection flow rate that was tested. Compressor flow range did improve slightly at zero injection due to the flow resistance created by injector openings on the hub surface. Leading edge loading and semi-vaneless space diffusion showed trends similar to those reported earlier from shroud surface experiments that did improve compressor flow range. Opposite trends are seen for hub injection cases where compressor flow range decreased. The hub injection data further explain the range improvement provided by shroud-side injection and suggest that different hub-side techniques may produce range improvement in centrifugal compressors.

14. SUBJECT TERMS

Centrifugal; Compressor; Stall; Surge

15. NUMBER OF PAGES

23

16. PRICE CODE

\begin{tabular}{|c|c|c|}
\hline $\begin{array}{c}\text { 17. SECURITY CLASSIFICATION } \\
\text { OF REPORT } \\
\text { Unclassified }\end{array}$ & $\begin{array}{c}\text { 18. SECURITY CLASSIFICATION } \\
\text { OF THIS PAGE } \\
\text { Unclassified }\end{array}$ & $\begin{array}{c}\text { 19. SECURITY CLASSIFICATION } \\
\text { OF ABSTRACT } \\
\text { Unclassified }\end{array}$ \\
\hline
\end{tabular}

NSN 7540-01-280-5500

Standard Form 298 (Rev. 2-89)

Prescribed by ANSI Std. Z39-18 298-102 

